\title{
PROFITABILITY OF ISLAMIC COMMERCIAL BANKS IN INDONESIA
}

Muhammad Tho'in Islamic Economics Institute of Economic Science (STIE) AAS

Surakarta, Indonesia thoin@stie-aas.ac.id

\begin{abstract}
This study aims to determine the profitability of Islamic commercial banks in Indonesia reviwed from the effect of NPF ratio and CAR ratio as intervening variable to ROA ratio in 2014-2016. The sampling technique of this research uses purposive sampling with the criteria of Islamic Commercial Banks which are registered in Financial Services Authority during period 2014 until 2016 and Islamic Banks which are consistently publish quarterly report period 2014-2016. The results show that there are 10 BUS with quarterly data amounting to 120 . This method of this research uses calculating path analysis method with the help of SPSS 23 program. The test that has been done shows that the NPF ratio has significant effect to ROA ratio which means that the bigger NPF ratio, the bigger cost of eliminating the financing reserve which resulted the income of Islamic commercial bank is decreasing, so it will have an impact to the decrease of ROA ratio. The NPF ratio significantly influences the CAR ratio, which means that the greater financing risk faced by Islamic commercial banks will increase the formation of allowance for earning assets losses from the equity held, thereby reducing the share of equity which is the component of the capital adequacy. CAR ratios are able to mediate an indirect effects of NPF ratios to $R O A$ ratios.
\end{abstract}

Keywords: profitability, Islamic Banks, Indonesia

\section{INTRODUCTION}

The growth development of Islamic commercial banks over the last few years can be said to be experiencing an increase, so there need an action to anticipate from this fierce competition. Because the fragility of the banking world, among others caused by the large proportion of credit or NPF financing problems (Non Performing Financing). The risk of bank loss due to non-current repayment of financing will affect the income and profit received by banks. So one of the parameters used in measuring the risk of Islamic commercial bank financing is Non Performing Financing (Veithzal, 2010: 971).

Furthermore, to measure bank's profitability performance is by return on asset ratio (ROA). This ratio will be able to explain and provide an overview of the analysts about either the bad state or the financial position of a company (Nuryanto et al., 2014). This 
ratio is used to measure the extent to which assets in particular earning assets (financing) owned by banks can generate profits that became the goal of the banking business. Return on asset provides information relating to efficiency performed by the bank, because return on assets (ROA) shows how much profit or profit which is generated on average from $\$ 1$ its assets. (Mishkin, 2008: 172).

The greater ROA shows that the company's performance is better, because the rate of return obtained is greater. In order to improve their profitability, Islamic commercial banks place the funds that have been collected in the form of financing both short-term and long-term.(Muhammad, 2005: 64).

To achieve optimal profitability, banks are faced with various risk, one of the risk is financing risk. The amount of financing risk besides can decrease the profitability, it can also affect health variables of other banks, namely capital. Africano (2016) states that capital is the ability of banks to provide capital for activities development and control the risks faced. The capital measurement of a bank is done by looking at Capital Adequacy Ratio (CAR). CAR is a ratio which related to bank capital factor to measure capital adequacy owned by bank to support risk-bearing assets. The capital amount of a bank will affect the ability or absence of a bank to efficiently run its activities.

Remembering the importance of the indicator on on the improvement of a company in the field of services, many researchers have been conducted related to the measurement of profitability of NPF (Non Performing Financing) can be said to have a significant effect on ROA (Return of Asset) (Rahman \& Rochmanika, 2012). On the other hand there are several studies which states that the indicator CAR (Capital Adequacy Ratio) also have a significant effect on ROA (Return Of Asset), ( Kurniawati, 2014). While Hutagalung et al. (2011), Eng (2013), Akhtar and Sadaqat (2011), Sudiyatno and Fatmawati (2013) indicate that CAR has no effect to ROA. Furthermore, Al-Parisi (2017) states that CAR has a positive significant effect to ROA.

Base on the explanation above. it that can be known that there is still problems or research gap, so the purpose of this study is to know the profitability of Islamic commercial banks in terms of financial ratios with a focus "The profitability of Islamic Commercial Bank in Indonesia Reviewed from the effect of NPF Ratio and CAR Ratio As Intervening Variables to ROA Ratio".

\section{LITERATURE REVIEW AND HYPOTESHIS}

\section{Non Performing Financing (NPF)}

The financial performance of the national banking system was better since the economic crisis that occurred in 1997. Banks began to generate profits and began to increase the amount of credit disbursed to the public. Implementation of non-performing financing (NPF) below $5 \%$ issued by Bank Indonesia shall make the Banks endeavor to comply the provisions.

So it can be interpreted that Non Performing Finance (NPF) is the risk due to the inability of customers to return the amount loans received from Islamic commercial banks and their remuneration in accordance with the term time specified (Mahmudah and Harjanti, 2016: 137). 


\section{Profitability ROA (Return On Asset)}

ROA is the result of return on assets in creating net income. In other words, this ratio is used to measure how much net profit will be generated from each dollar embedded on total assets ". (Murhadi, 2013: 228).

So it can be known that Return on Total Assets is a tool to measure the ability of companies in utilizing its assets to earn profits (Prastowo, 2008: 91).

\section{Capital Adequacy Ratio (CAR)}

Capital adequacy ratio (CAR) is the bank's ability to cover the risk of loss from its activities and the bank's ability to fund its operations ". Capital adequacy ratio (CAR) is used to cover assets as a result of the losses incurred. (Mokoagow and Fuady, 2015: 37).

Furthermore, Barus \& Sulistyo (2011) CAR is a ratio showing the total amount of all bank assets that contain elements of risk (credit, investments, securities, claims to other banks) that come funded from own capital in addition to obtaining funds from sources outside the bank.

\section{Effect of NPF on CAR}

The increase of NPF was caused by increase in non-performing financing to total financing held by banks.

This resulted in decreased bank income and decreased of bank profitability, so that bank capital will decrease and the CAR will be lower. Thus the NPF relationship to CAR is negative.

This is supported by the results of research Poernamawatie (2009), Margaretha and Setiyaningrum (2011) which in their research states that the variable NPF negatively affect the CAR.

H1: NPF ratio has significant effect to CAR ratio

\section{The effect of CAR to ROA}

Kuncoro (2011) stated that CAR is used to measure capital adequacy in Islamic commercial banks. Furthermore Zimmerman (1996) CAR is one of the variables that can be used as a measurement of bank performance, which is reflected in the CAMEL component ( Capital, Asset, Management, Earning, Liquidity).

According to Mahmudah and Harjanti (2016) if the Islamic commercial Bank has a high CAR it can increase ROA. The statement is supported by research conducted by Mokoagow and Fuady (2016) and Mahmudah and Harjanti (2016) which revealed that CAR affects on ROA. Furthermore, Sudiyatno and Suroso (2010) in their research stated that CAR variable has positive effect on ROA.

H2: CAR Ratio has significant effect to ROA ratio 


\section{Effect of NPF on ROA}

The NPF ratio is one of the measures used to determine the risks arising from the inability of customers to repay the loan and the rewards. A very high NPF can reflect that the Islamic commercial banks' financing is getting worse. Increasing the NPF will result in a loss of opportunity to earn income from the financing provided so it gives affect in earnings and adversely affect ROA (Wibowo and Syaichu, 2013).

NPF proportioned credit risk negatively affects the bank's financial performance proxyed by ROA. The results of research conducted by Kolapo et al. (2012), showed that Non Performing Loan (NPL) had a negative effect on Return On Asset and Mawadah (2015) stated that NPF has an effect to ROA.

H3: NPF ratio has significant effect to ROA ratio

\section{Effect of NPF on ROA with CAR as Intervening}

Poernamawatie (2009), Margaretha and Setyaningrum (2011) in their researches found that NPF has a negative influence on CAR. In addition, Syafri (2012) in his research found that NPF has a positive influence on ROA. Furthermore, Africano (2016) in the study stated that CAR mediates partially the effects of NPF and on ROA.

H4: CAR ratio mediates the influence of NPF on ROA

\section{METHODS}

The data which are required in this research are quarterly financial report data published by Islamic commercial banks through financial services authority website which is the object of this research in 2014-2016. Furthermore, the population used is all Islamic commercial banks and Islamic business units in Indonesia in 2014-2016 using purposive sampling as the technique to determine the sample.

The analysis technique in this research is by testing the classical assumption then the data analysis method used in this study using path analysis technique with the help of SPSS program. 


\section{RESULTS AND DISCUSSION}

\section{Classic Assumption Test Normality test}

\section{Equation I}

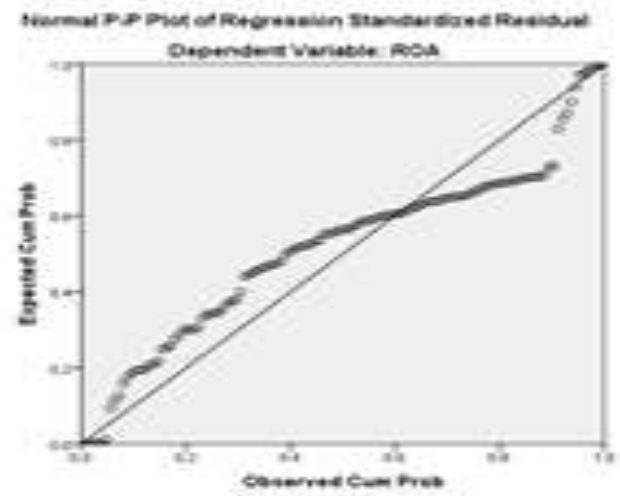

Equation II

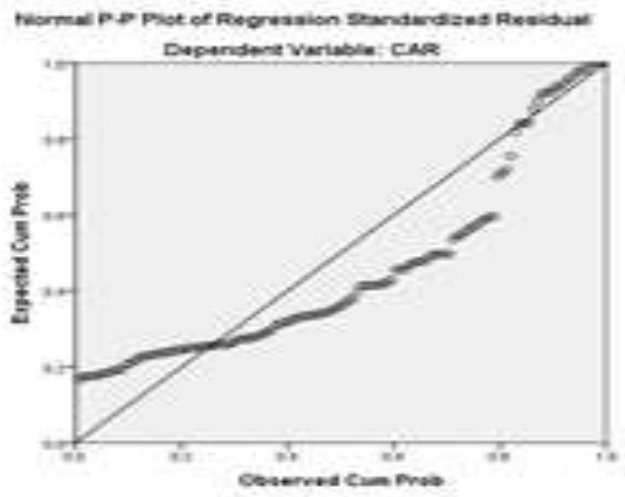

Figure 1. Normality test result of Islamic commercial bank in Indonesia

From Figure 1 above it is known that the criterion for knowing normal distributed data can be seen from from the figure above. Criteria of the test is that if the data inormally distributed is the distribution of dots following a straight line. So it can be concluded that for equation I and equation II can be concluded that the data consisting of NPF ratio with CAR ratio and NPF ratio, CAR to normal distributed ROA ratio.

\section{Multicollinearity Test}

Table 1. Multicollinearity test result of Islamic commercial bank in Indonesia

\begin{tabular}{lcc}
\hline & \multicolumn{2}{c}{ Collinearity Statistics } \\
\cline { 2 - 3 } (Constant) & \multicolumn{2}{c}{ Tolerance } \\
CAR & .918 & 1.090 \\
NPF & .918 & 1.090 \\
\hline
\end{tabular}

From the results of table 1 above is done for multicollinearity test to know the correlation of the independent variable $(X)$ or ratio variable of NPF and CAR ratio. It can be done with the test value criteria generated by the tolerance column not less than the determination value of $10 \%$ and the VIF value does not exceed the criterion of 10 . So it can be concluded that from the test results that have been done the value generated on the tolerance column and VIF of the data NPF ratio and CAR ratio are not $>10 \%$ and $<10$, which means no multicollinearity of NPF ratio and CAR ratio in Islamic Commercial Bank. 


\section{Autocorrelation Test}

Table 2. Autocorrelation test result of Islamic commercial bank in Indonesia

\begin{tabular}{ccc}
\hline \multicolumn{3}{c}{ Model Summary b } \\
\hline & Equation I & Equation II \\
Model & Durbin-Watson & Durbin-Watson \\
1 & 0.410 & 1.175 \\
\hline
\end{tabular}

Table 2 above shows that the value produced by Durbin Watson equation I is 0.410 and the equation II is 1.175. The value indicates that it is still between -2 to +2 , which means there is no autocorrelation. So it can be concluded that there is no autocorrelation from the equation I that is NPF ratio with CAR and equation II that is the NPF, CAR and ROA ratio.

\section{Heteroscedasticity Test}

Equation Test Results I

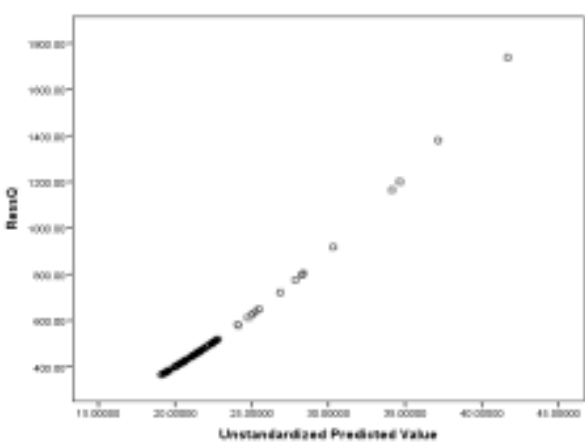

Equation Test Result II

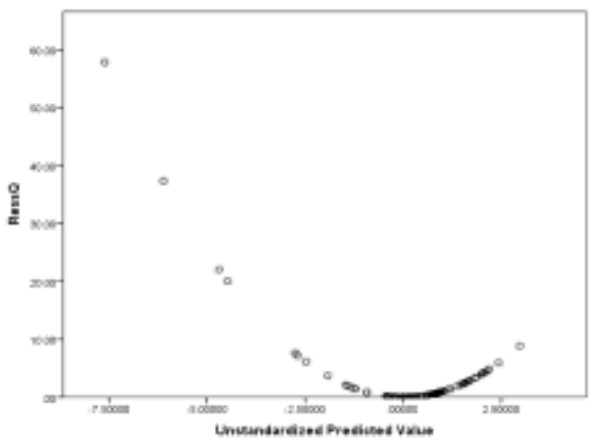

Figure 2. Heteroscedasticity test result of Islamic commercial bank in Indonesia

From figure 2 above shows the homocedasticity model because the variance of one observation residual to another observation remains, from equation I that is the NPF radio and CAR ratio and equation II from ratio of NPF, CAR and ROA. That is because the spread of data does not form a wavy pattern widened then narrowed. So it can be concluded that the model does not contain heteroscedasticity and is suitable for use in the model.

\section{Path Analysis}

$C A R=\alpha+\beta N P F+e 1$ (structural equation 1$)$

$R O A=\alpha+\beta N P F+\beta C A R+$ e 2 (structural equation 2)

Table 3. The magnitude effect of structural equation I and structural equation II

R Square

Structural Equation I Structural Equation II


From the results of the data in table 3 above it can be known that the magnitude of the effect of the NPF ratio to CAR ratio is $8.2 \%$. Furthermore, the effect of NPF ratio and CAR to ROA ratio is $45.4 \%$. So from these data can be known that there are many ratio variables that can affect CAR ratio and ROA ratio.

Table 4. The effect of structural equation I and structural equation II

\begin{tabular}{|c|c|c|c|c|}
\hline \multirow[t]{2}{*}{ Model } & \multicolumn{2}{|c|}{$\begin{array}{c}\text { Equation Structure } \\
\text { I }\end{array}$} & \multicolumn{2}{|c|}{$\begin{array}{l}\text { Equation } \\
\text { Structure II }\end{array}$} \\
\hline & $\mathrm{F}$ & Sig. & $\mathrm{F}$ & Sig. \\
\hline $\begin{array}{c}\text { Regression } \\
\text { Residual } \\
\text { Total }\end{array}$ & 10606 & $.001^{\mathrm{b}}$ & 48671 & $\mathrm{~b}$ \\
\hline
\end{tabular}

From the results of table 4 above can be known that the results of the equation structure 1 test is seen from the value of sig. .001, the value is less than the alpha value that is $5 \%$. So it can be seen that the regression model is feasible and significant with significance $0.001<\alpha(0.005)$. Furthermore, from the equation of structure 2 test that is equal to 0.000 , the value is still in criteria less than alpha, so from equation of structure 2 it can be known that the regression model is feasible and significant with significance $0.000<\alpha(0.005)$.

\section{The Influence of NPF ratio to CAR ratio}

Table 5. Effect of NPF Ratio to CAR Ratio

\begin{tabular}{cccl}
\hline & MODEL & $\mathrm{t}$ & Sig. \\
\hline 1 & Constant & 13606 & .000 \\
& NPF & 3.257 & .001 \\
\hline
\end{tabular}

From the results of table 5 it is known that the value generated by the value of $t$ count is 3.257 and the resulting sig value is .001 which means that the value is less than the alpha value that is $5 \%$. So it can be known that the regression model is feasible and significant with the significance of $0.001<a(0.005)$ or it can be said that there is a significant influence of the independent variable to the dependent variable.

\section{The Influence of NPF ratio to ROA ratio}

Table 6. Influence of NPF Ratio to ROA Ratio

\begin{tabular}{ccccc}
\hline & MODEL & $\begin{array}{c}\text { Unstandardized } \\
\text { Coefficients } \\
\text { B }\end{array}$ & $t$ & Sig. \\
\hline 1 & Constant & 1.489 & 7165 & .000 \\
& NPF & -.128 & -9.266 & .000 \\
\hline
\end{tabular}

From the results of table 6 it is known that the value generated by the value of $t$ calculate is -9.266 and the resulting sig value is .000 which means that the value is less than the alpha value that is $5 \%$. So it can be known that the regression model is feasible 
and significant with the significance $0.000<a(0.005)$ or it can be said that there is a significant influence of the independent variable to the dependent variable.

\section{The influence of the CAR ratio mediates the effect of NPF to the ROA ratio}

Table 7. Influence of CAR Ratio to Mediate Effect of NPF to ROA Ratio

\begin{tabular}{ccccc}
\hline MODEL & $\begin{array}{c}\text { Unstandardized } \\
\text { Coefficients } \\
\text { B }\end{array}$ & $t$ & Sig. \\
\hline 1 & Constant & .814 & 2.507 & .014 \\
& CAR & .035 & 2.658 & .009 \\
NPF & -.236 & -9.864 & .000 \\
\hline
\end{tabular}

From the results of Table 7 it is known that the value generated by the value of $t$ calculate $X_{1}$ is 2658 with the resulting sig value is equal to .009 which means that the value is less than the alpha value that is $5 \%$. Then it can be known that the $\mathrm{X} 1$ regression model is feasible and significant with the significance $0.000<\alpha(0.005)$ or it can be said that there is a significant influence of the independent variable (X1) to the dependent variable. As for the value of $t$ calculate $\mathrm{X} 2$ is equal to -9.864 with the resulting sig value is .000 which means that the value is less than the alpha value that is $5 \%$. So it can be known that the $X_{2}$ regression model is feasible and significant with the significance $0.000<\alpha(0.005)$ or it can be said that there is a significant influence of the independent variable $\left(\mathrm{X}_{2}\right)$ to the dependent variable.

\section{The Influence of NPF ratio to ROA ratio in Islamic commercial bank in Indonesia}

Based on the results of data calculation above, especially in table 4 that the regression model is feasible and significant with the significance of $0.000<a(0.005)$ or it can be said that there is a significant influence of the independent variable to the dependent variable. So it can be concluded that the ratio of NPF significantly influence the ROA ratio which means that the greater the ratio of NPF, the greater elimination cost of financing reserves that resulted in the income of Islamic commercial banks decreased, so that will also affect the decrease of ROA ratio. This is in accordance with the research conducted by Kolapo et al. (2012) which found that NPFs have an effect to ROA.

\section{Influence of NPF ratio to CAR ratio at Islamic commercial banks in Indonesia}

Based on the results of the calculation above, especially in table 3 that the regression model is feasible and significant with the significance of $0.001<a(0.005)$ or it can be said that there is a significant influence of the independent variable to the dependent variable. So it can be concluded that the ratio of NPF significantly influences the CAR ratio which means that the greater the risk of financing faced by Islamic commercial banks will increase the formation of allowance for earning assets losses from the equity owned, so that there is reduction of equity stock which is a component of capital adequacy. The results of this research are consistent with the research that has been done by Poernamawatie (2009), Margaretha and Setiyaningrum (2011) which found that a negative relationship between NPL and CAR, and Africano (2016) which stated that there is significant influence of NPF ratio to CAR ratio. 
The influence of CAR ratio mediates the effect of NPF to ROA ratio at Islamic commercial banks in Indonesia

Based on the results of table 5 it can be seen that the regression model of CAR ratio is feasible and significant with the significance of $0.000<a(0.005)$ or it can be said that there is a significant influence of the ratio of CAR to ROA ratio. When the capital of Islamic commercial banks is large enough and there is high competition, Islamic commercial banks will focus more on the growth of firm size, it means that Islamic commercial banks will encourage the increase of assets owned along with the increased capital of Islamic commercial banks. So in order to achieve the desired growth, Islamic commercial banks will reduce the spread which take effect in decreased profitability of Islamic commercial banks. This is in accordance with research conducted by Fuady (2016) and Mahmudah and Harjanti (2016) which revealed that the CAR affect to ROA. Furthermore Sudiyatno and Suroso (2010) in their research stated that the CAR ratio has a positive effect to ROA ratio.

The test of mediation variable from CAR ratio to ROA ratio can be seen from test result below:

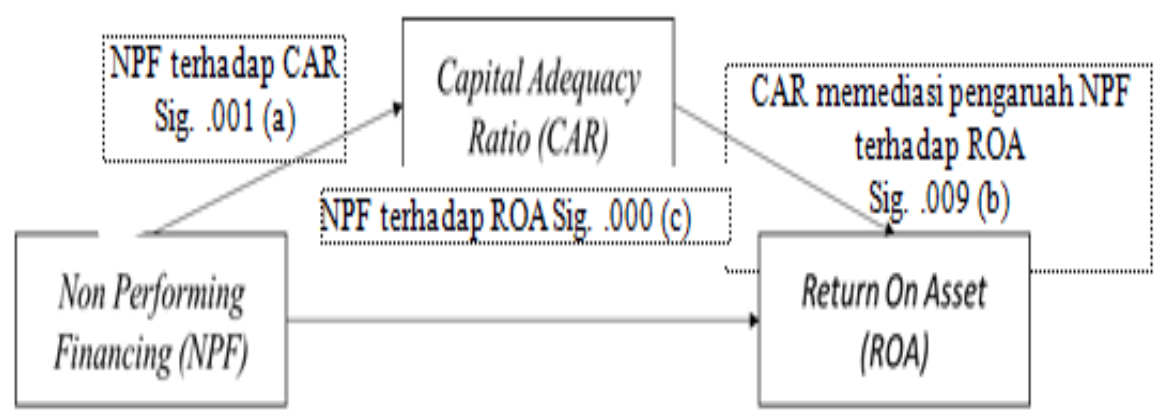

Figure 3. Influence of CAR Ratio to Mediate NPF Influence to ROA Ratio

Based on the result of calculation above, especially in Table 8 that the regression model is feasible and significant with the significance of $0.001<\alpha(0.005)$ or it can be said that there is a significant influence of the independent variable to the dependent variable through the intervening variable. So it can be concluded that the ratio of NPF has a significant effect to the ROA ratio or in other words the NPF ratio directly affect the ROA ratio because the resulting value is $000<0.05$ which means that the high NPF can reflect that the financing of Islamic commercial banks is getting worse.

Furthermore, if it is reviewed from the effect of CAR ratio as an intervening to the NPF ratio with ROA ratio, it is known that the value resulting from the value of the sig is .009. The value from the test criteria can be categorized as having an indirect effect where the value of $.009<$ alpha value 0.05 . So it can be concluded that the CAR ratio is able to mediate the indirect influence of NPF ratio to ROA ratio.

When it is viewed from the coefficient value (a), (b) and (c) all the resulting values are significant which means that it is sufficient to indicate the existence of mediation. If the coefficient $c$ is not significant, then occurs perfect or complete or full mediation. If the 
coefficient c decreases but remains significant, then it is stated partial mediation. So it can be concluded that the model includes partial mediation or mediation occurs.

\section{CONCLUSION}

The NPF ratio has a significant effect to ROA ratio which means that the bigger the NPF ratio, there is a greater cost of the financing elimination that resulted in the income of Islamic commercial bank is decrease, so it will also affect the decrease of ROA ratio. NPF ratio is significantly influence the CAR ratio, which means that the greater the financing risk faced by Islamic commercial banks will increase the formation of allowance for earning assets losses from the equity held, so that there is reducing the share of equity which is the capital adequacy component. There is a significant influence of CAR to ROA ratio. When the capital of Islamic commercial banks is large enough and the high competition condition, Islamic commercial banks will focus more on the growth of firm size, it means that Islamic commercial banks will encourage the increase of assets owned along with the capital increase of Islamic commercial banks. So it can be concluded that the CAR ratio is able to mediate the indirect influence of NPF ratio to ROA ratio.

\section{REFERENCES}

Africano, F. (2016). Pengaruh NPF terhadap CAR serta Dampaknya terhadap Profitabilitas Bank Umum Syariah di Indonesia. Jurnal IImiah STIE MDP, 6(1).

Kurniawanti, A. (2014). Analisis Faktor-Faktor Yang Mempengaruhi Volume Pembiayaan Berbasis Bagi Hasil Pada Bank Umum Syariah Di Indonesia.

Akhtar, M. F., Ali, K., \& Sadaqat, S. (2011). Factors influencing the profitability of Islamic banks of Pakistan. International Research Journal of Finance and Economics, 66(66), 1-8.

Al Parisi, S. (2017). Determinan Kinerja Keuangan Bank Umum Syariah di Indonesia. Ikonomika, 2(1), 41-52.

Barus, A. C., \& Sulistyo, D. (2011). Hubungan Efesiensi Operasional dengan Kinerja Profitabilitas pada Sektor Perbankan yang Go Public di Bursa Efek Indonesia. Jurnal Wira Ekonomi Mikroskil: JWEM, 1(2).

Eng, T. S. (2013). Pengaruh NIM, BOPO, LDR, NPL \& CAR Terhadap Roa Bank Internasional Dan Bank Nasional Go Public Periode 2007-2011. Jurnal dinamika manajemen, 1(3).

Hutagalung, E. N., \& Ratnawati, K. (2013). Analisa Rasio Keuangan terhadap Kinerja Bank Umum di Indonesia. Jurnal Aplikasi Manajemen, 11(1), 122-130.

Kolapo, T. F., Ayeni, R. K., \& Oke, M. O. (2012). Credit Risk And Commercial Banks Performance In Nigeria: A Panel Model Approach. Australian journal of business and management research, 2(2), 31.

Kuncoro, M. (2011). Metode Kuantitatif: Teori dan Aplikasi untuk Bisnis \& Ekonomi. Yogyakarta: Upp Stim Ykpn. 
Mahmudah, N., \& Harjanti, R. S. (2016, May). Analisis Capital Adequacy Ratio, Financing To Deposit Ratio, Non Performing Financing, Dan Dana Pihak Ketiga Terhadap Tingkat Profitabilitas Bank Umum Syariah Periode 2011-2013. In Prosiding Seminar Nasional IPTEK Terapan (SENIT) 2016 Pengembangan Sumber Daya Lokal Berbasis IPTEK (Vol. 1, No. 1).

Margaretha, F., \& Setiyaningrum, D. (2011). Pengaruh Resiko, Kualitas Manajemen, Ukuran dan Likuiditas Bank terhadap Capital Adequacy Ratio Bank-Bank yang Terdaftar di Bursa Efek Indonesia. Jurnal Akuntansi dan Keuangan, 13(1), 47-56.

Mawaddah, N. (2015). Faktor-faktor yang mempengaruhi profitabilitas bank syariah. Jurnal Etikonomi, 14(2).

Mishkin, F. S. (2008). Ekonomi Uang, Perbankan, dan Pasar Keuangan. Jakarta: Salemba Empat.

Muhammad., (2005). Manajemen Pembiayaan Bank Syariah. Yogyakarta: (UPP) AMP YKPN.

Murhadi, W. R. (2013). Analisis Laporan Keuangan: Proyeksi dan Valuasi Saham.

Mokoagow, S. W., \& Fuady, M. (2015). Faktor-Faktor yang Mempengaruhi Profitabilitas Bank Umum Syariah di Indonesia. EBBANK, 6(1), 33-62.

Nuryanto, R., Tho'in, M., \& Wardani, H. K. (2014). Rasio Likuiditas, Rasio Solvabilitas, Rasio Rentabilitas Koperasi Jasa Keuangan Syariah Di Jawa Tengah. Jurnal Akuntansi dan Pajak, 15(01).

Poernamawatie, F. (2009). Pengaruh Risiko Kredit Terhadap Kinerja Keuangan pada Bank-Bank Persero yang Terdaftar di BEl. Jurnal Manajemen Gajana, 6(1), 71-90.

Prastowo, D., \& Juliaty, R. (2008). Analisis Laporan Keuangan: Konsep dan aplikasi, edisi kedua. Yogyakarta: UPP STIM YKPN.

Rahman, A. F., \& Rochmanika, R. (2012). Pengaruh Pembiayaan Jual Beli, Pembiayaan Bagi Hasil, dan Rasio Non Performing Financing terhadap Profitabilitas Bank Umum Syariah di Indonesia. IQTISHODUNA.

Sudiyatno, B. (2013). Pengaruh Risiko Kredit dan Efisiensi Operasional terhadap Kinerja Bank (Studi Empirik pada Bank yang Terdaftar di Bursa Efek Indonesia). Jurnal Organisasi dan Manajemen, 9(1), 73-86.

Syafri, M. (2012, September). Factors affecting bank profitability in Indonesia. In The 2012 International Conference on Business and Management (Vol. 237, No. 9, pp. 7-8).

Veithzal, R., \& Arifin, A. (2010). Islamic Banking: sebuah teori, konsep, dan aplikasi. Sistem Bank Islam Bukan Hanya Solusi Menghadapi Krisis Namun Solusi dalam Menghadapi Berbagai Persoalan Perbankan dan Ekonomi Global.

Wibowo, E. S., \& Syaichu, M. (2013). Analisis pengaruh suku bunga, inflasi, car, bopo, npf terhadap profitabilitas bank syariah. Diponegoro Journal of Management, 2(2), 10-19. 


\section{Profitability Of Islamic Commercial Banks In Indonesia}

Zimmerman, G. C. (1996). Factors influencing community bank performance in California. Economic Review-Federal Reserve Bank of San F 